\title{
Evaluating Strategies for Ranching in the 21st Century: Ranching in the Ethanol Era
}

\section{By James Mintert}

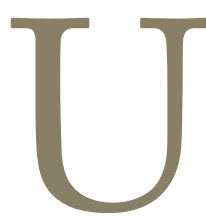

$S$ ranchers face a big challenge in the years ahead. Feed grain prices have increased dramatically in the last two years and are likely to remain high relative to historical averages. The rise in feed grain prices is putting upward pressure on land prices, land rental rates, and forage values. In addition, other production costs such as fuel and fertilizer have increased dramatically, leading to even more upward pressure on operating costs. The increase in feed grain prices is being felt another way by US ranchers in the form of lower calf prices, as cattle feeders respond to higher feed prices by lowering prices they are willing to pay for calves and feeder cattle. The result, which is ongoing, is a sharp narrowing of operating margins for US ranchers that will leave some cow-calf operations unable to cover their variable costs of production in the near future. The inability to cover variable production costs is expected to lead some ranchers to reduce the size of their cow herds and, ultimately, lead to a smaller US beef cow herd. To assess how this changing economic environment will affect ranchers, it is useful to examine some of the underlying forces driving this changing economic environment to determine what it means from a long-run perspective.

\section{Corn Usage and Ethanol}

Usage of corn has been increasing significantly for decades. To put this in perspective, examine total corn usage data published by the United States Department of Agriculture's World Agricultural Outlook Board. In the early to mid1970s US corn usage (including exports and all sources of domestic demand) ranged from about 5 to 6 billion bushels per year. Total corn usage increased steadily over the next three decades, finally exceeding 10 billion bushels during the
2003 crop year. But recently, total corn usage has skyrocketed, increasing at a rate far exceeding the long-term trend, primarily because of increasing demand for corn used to produce ethanol.

As recently as the 2002 crop year, about 1 billion bushels of corn were used to produce ethanol in the United States (Fig. 1). This increased rapidly over the ensuing four years, reaching 2.1 billion bushels consumed for ethanol production during the 2006 crop year. Furthermore, USDA projects that corn used to produce ethanol will total 3.2 billion bushels during the 2007 crop year. As additional ethanol production capacity comes on line in 2008 and 2009, corn used to produce ethanol will increase even more. During the 2008 crop year, corn used to produce ethanol is expected to increase sharply compared to 2007 , likely ranging from 3.5 to about 4.1 billion bushels, as additional ethanol plants come online. Looking further ahead, the new Renewable

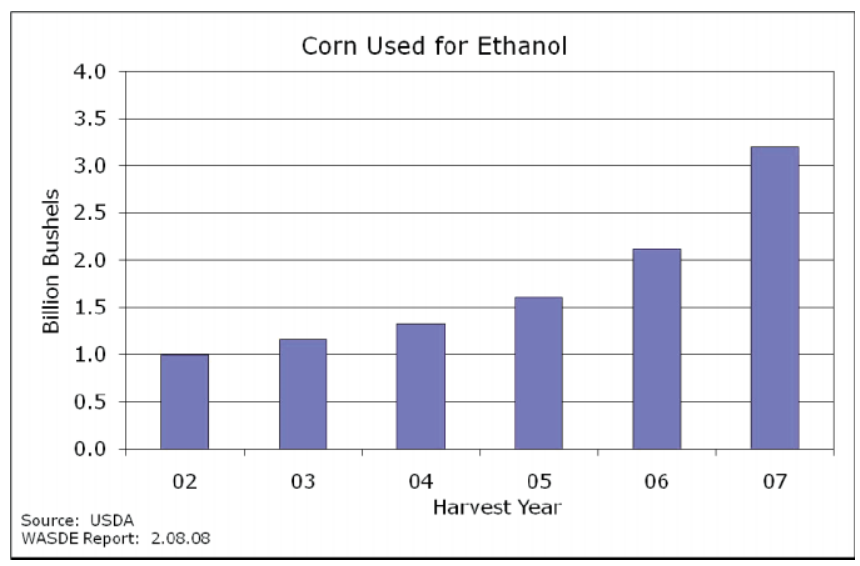

Figure 1. Corn used for ethanol. 
Fuels Standard outlined in the Energy Independence and Security Act of 2007 enacted in December 2007, will continue to strongly encourage ethanol production. The 2007 Energy Act mandates that total renewable fuels in the United States will reach 36 billion gallons by 2022, with a maximum of 15 billion gallons of renewable fuels coming from corn starch. Furthermore, USDA projects that ethanol production from corn starch will hit 15 billion gallons by 2015. Thus, this huge new source of corn demand will continue to have a dramatic impact on the corn and livestock markets in the years ahead.

One way to assess the relative importance of corn used for ethanol production in the United States is to compare it to corn used for feed (Fig. 2). This is an important comparison because, historically, feed was the largest single usage category for corn. Calculations made using data published by USDA indicate that, in 2002, before ethanol production really started to escalate, approximately $11 \%$ of corn production was devoted to ethanol production. That same year, $62 \%$ of US corn production was devoted to feed usage. Ethanol production consumed a growing share of US corn production throughout the first decade of the new millennium, and USDA's projections imply that about $24 \%$ of the 2007 corn crop will be devoted to ethanol production. At the same time, the percentage of US corn production devoted to feed usage was falling steadily. For example, in the 2007 crop year, USDA data indicates feed usage is expected to total just $46 \%$ of US corn production. Looking ahead to 2008 , ethanol could easily consume $30 \%$ of the 2008 US corn crop with feed usage comprising just 45\% of total US corn usage. As ethanol production continues to increase, it's clear that corn used to produce ethanol could soon exceed corn used for feed, marking a dramatic shift in the composition of corn demand in a span of less than a decade.

The sharp rise in corn usage over the last several years pushed corn prices up very quickly. Estimates of corn prices published by USDA indicate that the national average corn

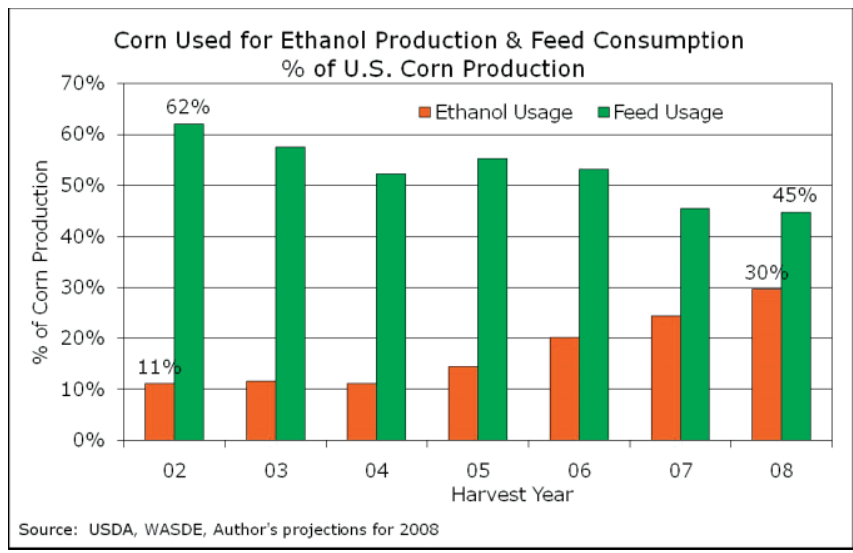

Figure 2. Corn used for ethanol production and feed consumption, as a percentage of US corn production. price during the 2005 crop year was just $\$ 2.00$ per bushel. During the 2006 crop year, corn prices increased about 50\% above the prior year, averaging $\$ 3.04$ per bushel, and USDA projects that the national average corn price during the 2007 crop year could rise by yet another one-third and reach $\$ 4.00$ per bushel. Comparing these recent price estimates to several long-term price averages makes clear how dramatic the shift in the corn price structure really is. For example, USDA's estimate of national average corn prices from the 1991 through 1995 crop years averaged $\$ 2.49$ per bushel; from 1996 through 2000 national corn prices averaged $\$ 2.15$ per bushel; and from 2001 through 2005 corn prices again averaged $\$ 2.15$ per bushel. Thus, USDA's $\$ 3.52$ per bushel preliminary estimate of the 2006-2007 national corn price average is about $63 \%$ above the corn price average from 1996 through 2005.

\section{Scenario Analysis: Examining Possible Corn Yield and Price Scenarios}

When assessing how much impact the changing feed grain price environment will have on the cattle sector it is useful to apply scenario analysis to see what could happen and, importantly, to see how changing some of the key assumptions alter the scenario. Although it is not possible to accurately project exactly how acreage, yields, production, and prices will turn out in 2008, it is useful to start off the year with a baseline scenario to try and determine whether the observed run-up in corn prices that took place during 2006 and 2007 is temporary or a long-run shift that necessitates adjustments by cattle industry stakeholders. Doing so requires assessing what could happen to corn acreage, corn yields, and corn usage during the upcoming crop year and considering what the impact of various outcomes will be.

Corn production in a given year is the result of harvested corn acreage multiplied by the national average corn yield, so estimating 2008 corn production requires that we obtain both acreage and corn yield estimates. Corn acreage increased dramatically in 2007 as planted corn acreage totaled 93.6 million acres, which was the largest corn acreage since the end of World War II and about 19\% greater than in 2006 (Fig. 3). But corn acreage could fall below the 2007 level in 2008 because corn production costs have escalated and prices for competing crops, especially soybeans and wheat, have risen sharply. Indeed, USDA's preliminary 2008 estimate of corn planted acreage released in early February 2008 indicated that corn planted acreage might decline to about 88 million acres, approximately 6\% lower than in 2007. When forecasting yields, it is important to account for the impact improving technology has on yields. Since the mid-1990s, national average corn yields have been increasing at the rate of about 2.5 bushels per acre per year. Based on the trend in corn yields since the mid-1990s, an initial estimate of the 2008 national average corn yield is 156.7 bushels per acre, which is about 5.6 bushels per acre higher than in 2007, but still 3.7 bushels per acre below the 


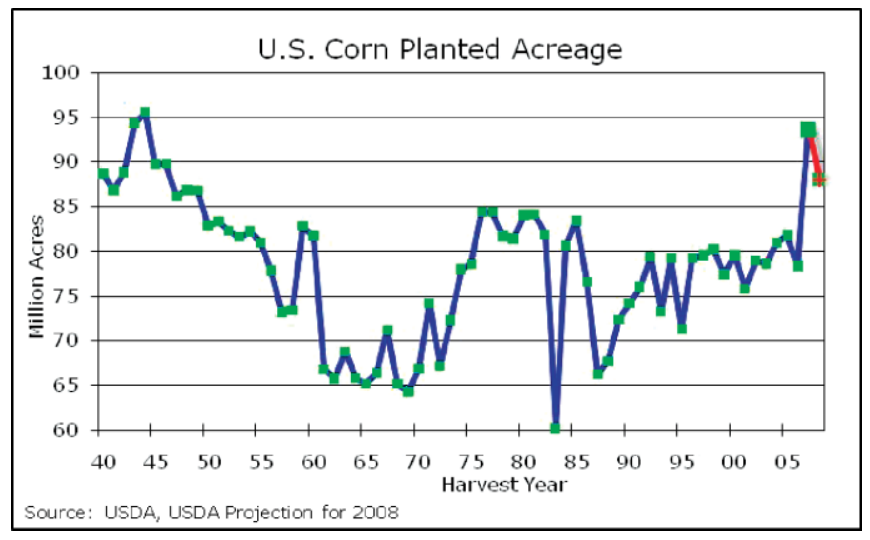

Figure 3. US corn planted acreage.

record high yield of 160.4 bushels per acre in 2004 (Fig. 4). Assuming the recent relationship between planted and harvested acreage holds true, this obtains a 2008 corn production estimate of 12.6 billion bushels, which is the second largest corn production estimate on record and just $3.5 \%$ below that of 2007 .

A standard approach to analyzing the relative balance of corn supply and demand is to construct a balance sheet that itemizes sources of supply and demand. Supply sources include carryover stocks from the prior year, imports, and production. Demand sources include domestic feeding, exports, and food and industrial uses, which includes corn used to produce ethanol. The big growth area in corn usage is in the ethanol sector. Although USDA indicates that corn used for ethanol production could reach 4.1 billion bushels during the 2008 marketing year as new ethanol plants continue to come on line, uncertainty regarding how quickly plants might be completed suggests that it is reasonable to start off by considering a more modest increase to approximately 3.75 billion bushels, which is still $17 \%$ higher than USDA's projection for 2007. Assuming that high corn prices discourage both feed usage and corn exports somewhat compared to 2007 , total corn usage in 2008 might

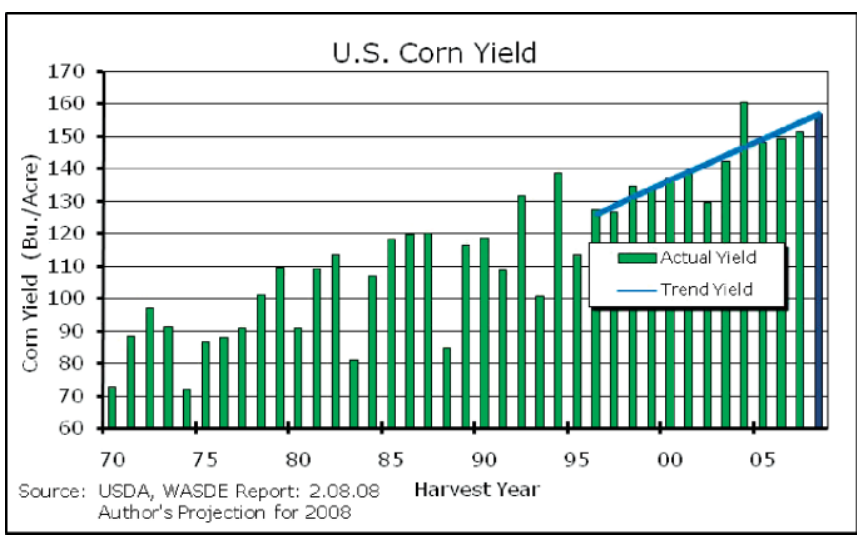

Figure 4. US corn yields. wind up near the projected total corn usage for 2007 of 12.995 billion bushels.

Following the balance sheet approach to estimating the corn carryover at the end of the 2008 marketing year (e.g., ending stocks in late summer 2009 before the 2009 harvest begins), reveals that ending stocks are likely to be near 1 billion bushels. Ending stocks at this level implies that stocks might equal just $8 \%$ of corn usage (Fig. 5). This is significant because, historically, ending stocks at less than $10 \%$ of total usage have signaled very tight supplies, leading to high corn prices that ration usage, and relatively high corn price volatility. In particular, this scenario reveals that, even with trend line yields and the second highest corn planted acreage since the 1940s, US corn stocks are likely to remain tight not only through the summer of 2008, but into, and probably beyond, 2009.

At this point, it is useful to consider other possible scenarios. For example, what might happen if corn yields in 2008 reach the record level obtained in 2004? A national average corn yield of approximately 160 bushels per acre does moderate the tight corn stocks situation, but it does not eliminate it. Under this scenario, holding corn acreage and all usage categories constant, corn ending stocks at the end of the 2008 marketing year could wind up near $11 \%$ of total usage, which is about equal to the stocks/use ratio projected at the end of the 2007 crop year. Conversely, if yields fall modestly below the trend and approximately equal the 2006 yield of 149 bushels per acre, ending stocks in late summer 2008 could wind up near or below 5\%, which is the tightest level observed over the last 35 years. Carryover at this level would imply even higher prices than we have observed so far in the 2007 marketing year, because higher prices would serve to ration usage among competing uses for corn. Note that this is not a "severe drought" scenario, but rather a situation where yields fall about $5 \%$ below the expected trend line yield. To put this in perspective, over the last half century, actual corn yields fell approximately $10 \%$ or more below the trend line yield over $15 \%$ of the time so yields could easily fall $5 \%$ below trend.

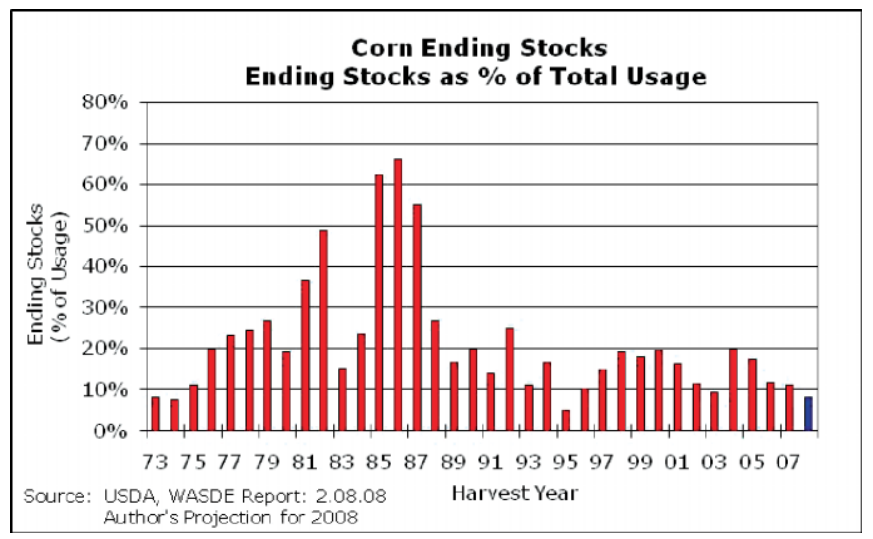

Figure 5. Corn ending stocks as a percentage of total usage. 


\section{Implications for Ranchers}

Ethanol will continue to consume a large, and growing, percentage of US corn production in the future. The corn balance sheet scenario analysis revealed that, even with trend line yields, corn stocks are expected to remain tight, resulting in average corn prices that are very high by historical standards. Furthermore, tight corn stocks are expected to lead to more volatile corn prices than typically observed in the past. As feed costs rise, and feed price volatility increases, cattle producers, especially cattle feeders and backgrounders, will find that the payoff to managing feed price risk is larger than in the past. Finally, it is important to note that high feed prices will, over time, exert downward pressure on calf prices. The reason is straightforward.

The beef industry is comprised of several different production segments, starting with the cow-calf sector. But after calves leave the ranch, the other production segments can best be characterized as margin operations. Margin operations respond to increases in their production costs (assuming their output price is held constant), by reducing the price they are willing and able to pay for their primary input, in this case calves and feeder cattle. So, as cattle feeders respond to high feed costs by reducing prices they are able to pay for feeder cattle, stocker operators and backgrounders respond in kind by reducing the prices they are able to pay for calves. Cow-calf operations are not able to pass the reduction in calf price on to another segment of the industry. Instead, cow-calf operations wind up absorbing the lower price they receive for calves by accepting a lower return for their land, capital invested, labor, and other resources devoted to cow-calf production.

How, then, does the industry ultimately pass on the rapid run-up in feed grain prices, fuel, fertilizer, and other inputs to consumers? Assuming domestic demand and export demand both hold constant, cow-calf producers bear the brunt of the increase in production costs in the form of lower returns. Ultimately, lower returns will lead higher cost cow-calf operations to reduce herd size and market fewer calves. The reduction in beef supplies that results from a smaller calf crop will finally force retail beef prices higher which, in turn, will cause wholesale beef prices to increase. Higher wholesale beef prices will, over time, be reflected in higher slaughter cattle prices and cattle feeders will respond to higher slaughter cattle prices by paying more for feeder cattle and calves. So, in the long-run, higher production costs will be reflected in higher calf prices, but, holding all else constant, a downsizing of the industry will be required before calf prices actually reflect the increase in production costs.

How quickly will this industry restructuring occur? Kansas Farm Management Association preliminary data for 2007 suggest that returns for average cost cow-calf operations were much narrower than just a couple of years ago (Fig. 6). Although most operations earned returns that were

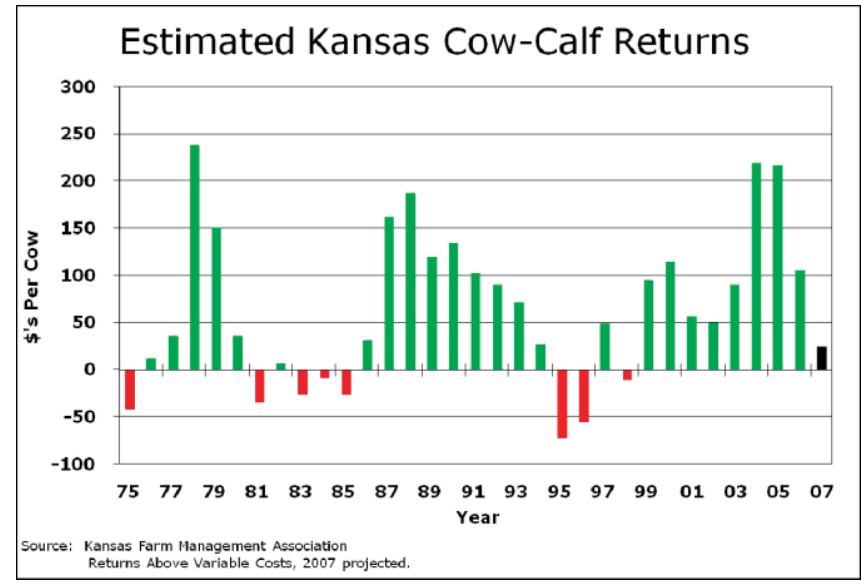

Figure 6. Estimated Kansas cow-calf returns.

greater than variable costs of production in 2007, returns could easily fall below variable production costs in 2008 as costs continue to escalate. As a result, downsizing the US beef cow herd could get underway in 2008 .

Another key change already underway that ranchers need to consider is the shifting price slide structure for feeder cattle and calves. In particular, price spreads between light and heavy weight steers and heifers will continue to decline. The reason is, as feeding costs of gain climb in feedlots, cattle feeders generally prefer to buy heavier, rather than light, feeder cattle, which causes the per hundredweight (cwt) price premium for light weight cattle to erode. As an example, consider how this price spread behaved over the last several years. During 2005 prices for 500-600 pound steer calves in Kansas averaged $\$ 17.68$ per cwt higher than prices for 700-800 pound feeder steers. Rising feed costs caused the spread to decline to $\$ 15.97$ in 2006 and $\$ 13.52$ in 2007. For ranchers, this means the market is providing a greater incentive than in the recent past to add weight to cattle before shipping them to feedlots. The key is to recognize the true value of the added gain and make sure the cost of putting on the additional weight is less than the revenue gain. To see this more clearly, consider the annual average price relationships that were in place in 2005 vs. 2007.

During 2005, prices for 500-600 pound steers in Kansas averaged $\$ 131$ per cwt, whereas prices for $700-800$ pound steers averaged $\$ 113.31$ per cwt. As a result, an average 550pound steer sold for $\$ 720.50$ per head, whereas a 750 pound steer sold for $\$ 849.83$ per head. Based on these price relationships, the revenue gain to a rancher that put 200 pounds of gain on a 550 pound steer and sold it weighing 750 pounds for $\$ 113.31$ per cwt would be $\$ 129.33$ per head. Dividing the revenue gain by the additional weight means the 200 pounds of gain generated marginal revenue of $\$ 0.65$ per pound. Performing the same calculations using 2007 average price relationships reveals that the marginal revenue for the additional 200 pounds of weight increased to $\$ 0.73$ per pound as the price spread narrowed to $\$ 13.53$ 
per cwt. Looking ahead to 2008, if the price spread between a 550 - and 750 -pound steer declines to $\$ 9.00$ per cwt, the marginal revenue gain derived from adding 200 pounds of gain will be near $\$ 0.80$ per pound. The challenge for ranchers will be to identify the actual revenue gain that can be derived from selling heavier steers and heifers and add weight to calves, utilizing lower cost feedstuffs, primarily forages and byproducts, which keep their costs of gain down.

Managing a cow-calf operation over the next several years will be a challenge. If it's not already in place, a management information system will be critical to survival. Knowing actual production costs, and benchmarking costs against industry standards, makes it possible to manage costs effectively. Successful operations in the years ahead will be those that know their costs and aggressively manage their costs to hold down their cost per cwt of calf produced to ensure that they are a low-cost operation that survives the industry restructuring that lies ahead.

\section{Additional Reading}

Kansas Farm Management Association. 2008. Profit center analysis: 5-year average. And 2006, beef cows, sell calves: state averages. Available at: http://www.agmanager.info/farmmgt/ income/enterprise/2006/default.asp. Accessed 19 February 2008.

US Department of Agriculture, Economic Research SERvice. 2008. February 2008 USDA agricultural projections to 2017. Washington, DC, USA: USDA. Available at: http://www. ers.usda.gov/publications/oce. Accessed 19 February 2008.

US Department of Agriculture, World Agricultural OutLOOK BOARD. World agricultural supply and demand estimates. Various issues, 1973-2008. Washington, DC, USA: USDA. Available at: http://usda.mannlib.correll.edu/MannUsda/view DocumentInfo.do?documentID=1194. Accessed 20 March 2008.

Author is Professor, Department of Agricultural Economics, Kansas State University, Manhattan, KS 66506, USA, jmintert@ksu.edu. 